\title{
Normative and Audience Discourses on Public Service Journalism at a "Critical Juncture": the Case of TVE in Spain
}

\section{To cite this article:}

María Lamuedra, Concha Mateos Martín \& Manuel A. Broullón-Lozano (2018)

Normative and Audience Discourses on Public Service Journalism at a "Critical Juncture": the Case of TVE in Spain, Journalism Studies, DOI:

10.1080/1461670X.2018.1528880

\begin{abstract}
The concept of journalism, its metatheory and, in particular, public service journalism is regulated by feedback between political models (legal and normative framework), academic precepts and social practices. Scant attention has been paid to date to the impact that these models have on citizens' discourses, which is especially relevant at "critical junctures", i.e. periods in which the old institutions are collapsing and require renovation (McChesney, 2007). Hence, this paper addresses the issue in the Spanish context in order to explore the similarities and differences between the academic/legal/normative framework and audience discourses. The former has been studied using documents, reports and legislation, and the latter explored by means of discussion groups with viewers of the newscasts of Television Española (TVE).
\end{abstract}

Keywords: Public Service Journalism; Media Democracy; Normative Framework; TVE; Metajournalism; Critical Juncture; Audience Discourses; Reception Analysis. 


\section{Article}

We are experiencing what R. McChesney (2007) has described as a "critical juncture", a period in which the old institutions are collapsing and require renovation. The resulting ones will be locked in place until the following juncture. In the current setting, which is increasingly being described with the term "post-democracy" (Crouch 2004), journalism is in "freefall collapse" (McChesney 2015, xxxviii). In light of media research data, authors such as Hackett and Carroll (2006), McChesney (2007, 2015) and Aslama and Nieminen (2017) are calling for media reform in order to shape a more democratic media ecosystem. And what is relevant in this context is to rethink the role of public service journalism in a "democratising" metajournalistic theory that reshapes professional practice and influences society.

Thus, this paper explores normative and citizens' discourses on journalism in general and on the national public service broadcaster Televisión Española (TVE) in particular. ${ }^{1}$ The Spanish scenario shares basic similarities with the general trends described by authors such as McChesney. In particular, Spain is currently immersed in a profound economic, social and political crisis, characterised by three factors: (1) the economic and financial turmoil resulting from the adjustments made to the liberal capitalist model (austerity policies) triggered a wave of social unrest and protests as from the end of 2010; (2) this led to the simultaneous emergence of new political parties and practices; (3) protesters' communities have, in many cases, adopted an active role in communication and information practices.

In this context, Spain is a case in which it is especially interesting to explore the perception that viewers have of the news media, given that, according to the results of the study performed by Amy Mitchell et al. $(2018,8)$ for the Pew Research Center, it is - together with Sweden and Germany - one of the three countries where the majority of citizens (88\%) believe that the media are important $(29 \%)$ or very important $(59 \%)$ for the proper functioning of society; and, what is more, they admit to having very little confidence in the news media.

This study analyses data gathered from five Spanish TVE viewers' discussion groups on news and journalism, exploring citizens' discourses on journalism in general and on national public service television in particular. Specifically, it examines to what extent citizens are aware of the current normative framework of journalism, particularly the public service kind.

Carlson's (2016) metajournalism theory provides a suitable scheme for studying the relation dynamics between "news texts, the practices that produce them, or the conditions of their reception" (ibid., 350). The theory departs from the premise that, firstly, social acceptance is a prerequisite for a profession to establish cultural authority and, secondly, this acceptance emanates from social discourses, which are seen as a dominant force delimiting how journalism is understood, shaped and accepted. They arise from both (1) the exercise of institutionalised news practices and (2) through explicit interpretive processes justifying or challenging these practices and their practitioners (Carlson 2016, 350). Social communication ends up being regulated by legal standards, professional codes of conduct - influenced by academic consensus taught in communication studies - and social values (normative discourse, ND). The aim here is to define and contrast the presence of normative discourses and audience discourses (AD) in a context of journalism and social change and flux.

We agree with Fiske's notion that discourse "is structured and structuring for it is both determined by its social relations and affects them" (in ibid., 253). Carlson's theory of metajournalism demands paying serious attention to non-journalistic sites on which audiences talk about journalism (ibid., 358) and research the processes of meaning formation (ibid.,

\footnotetext{
${ }^{1}$ In Spain there are also regional public media corporations in 12 of the 17 Spanish regions, comprising FORTA (Federación de Organismos de Radio y Televisión Autonómicos), in addition to numerous local public radio and television stations depending on local council funding.
} 
364). Citizens' discourses on journalism do indeed have a strategic influence on metajournalistic discourses, in the form of "expected expectations" (Schmidt 2008, 67) but can only be considered metajournalistic discourses per se in a truly participatory definition of journalism.

Audience studies describe a tendency and (an academic) desire for a more participatory relationship between journalists and audiences. For instance, Heise et al. (2013) assume that the audience "is included" in the main German public newscast and explore perceptions about this, while Van der Wurff and Klaus Schönbach (2013) depart from the news media's incorporation of accountability measures to be used by citizens, with a view to assessing their discourses on three practices of accountability: transparency, responsiveness and interaction. The academic literature frames this process in a context marked by technological change (van Dijck and Poell 2015), declining levels of public trust in the news and competition in the private sector.

All things considered, the following sections offer a brief overview of legal, professional and academic norms, values and contexts regarding journalism and public service television, i.e. which hypothetically set the conceptual boundaries for metajournalistic discourse. In order to remain within the word count, the sources of these two sections have been chosen for their capacity to represent trends and wider views, whilst combining an international perspective and the need to describe a national context. The first section offers a description of the political space of journalism in representative democracies, particularly in the Spanish case. Secondly, the normative framework of public service journalism is provided. This implies paying attention to (1) the most consensual academic notions about the role of public service journalism and (2) the limits within which public communication operates in Spain, as summarised in an International Press Institute report drawn up after a process of dialogue with 30 social agents. It also outlines (3) the basics of the legal framework governing public service journalism in Spain. Later, the methodology employed is discussed. In view of the legal, academic and professional normative discourses (ND), an analysis of audience discourses (AD) is undertaken, and finally, a number of conclusions are drawn.

\section{The political nature of journalism in democracy}

Representative democracies require citizen participation in political elections. Their proper functioning is affected by the information that citizens use in their political decisionmaking, for which reason in this type of system they delegate three times: (1) legislative and executive power to people who are considered trustworthy and meritorious, (2) on the strength of the information circulated by the media and (3) who must also control the political powers. It is self-evident that the role of journalism in these representative processes is so strategic that it should be protected by democratic states. It must be acknowledged that at least some elements in the process of shaping public opinion, such as freedom of expression, have been enshrined as fundamental rights in international laws - i.e. the Universal Declaration of Human Rights (Art. 19) and the European Convention of Human Rights (Art. 10) - and news in election campaigns tends to be subject to stricter norms.

If public opinion dynamics were defective in any way, election results would be flawed, without truly representing the aspirations and interests of the majority of civil society. The fact that this is actually happening at the moment is at the heart of the theory of deliberative democracy (Velasco 2009, 26-77; Nino 1997, 224-228) and one of the main reasons behind its call to transcend representative democracy, precisely to focus on the need to construct virtuous public spheres. Interestingly enough, the importance of building public opinion was 
acknowledged by the Spanish Constitutional Court in similar terms (in a representative democracy) when asserting that, without unrestricted public communication,

...other rights enshrined in the Constitution would be vacated of any real content, the representative institutions reduced to vacuous forms and completely distorting the principle of democratic legitimacy enunciated in article 1.2 of the Constitution, which is the basis of all our legal-political regulations (Judgement 6/1981).

In accordance with this point of view, the Spanish Constitution (hereinafter, SC) establishes (1) the obligation of the mass media to offer truthful information (Article 20.1), viz. subject to professional journalistic standards (Azurmendi 2005), and (2) to guarantee pluralism and the right of access of the main social groups to public media channels (Article 20.3).

\section{The normative framework of public service journalism}

Firstly, the academic literature has defined public television in a variety of ways, but always focusing on the same interconnected functions:

(1) to provide plural and quality information of public interest,

(2) so as to allow citizen participation and public debate,

(3) thus fostering the community's cultural cohesion.

According to Coleman (2002, 90), "A public broadcasting service cannot retreat from public information. Service implies duty." To this end, it needs to be protected from and independent of political and economic powers (Larsen 2014, 65; Cushion 2012; García-Avilés 2011, 177; Dahlgren 2009; Humphreys 2008; Moe 2008; Coleman 2002; Steemers 2001).

According to the review conducted by Born and Prosser $(2001,671)^{2}$ on recent studies in this field, there is a general consensus on three principles: "(1) enhancing, developing and serving social, political and cultural citizenship; (2) universality; and (3) quality of services and of output."

However, there is a broad international consensus that these principles are not being complied with, but on the contrary public service journalism serves the elites as explored by R. McChesney and McNichols (2010) in the USA, J. Schlosberg (2013) in the UK, and P. Serrano (2010) in Spain, among many others. Hence, the journalism provided by public broadcasting corporations does not always fulfil the aforementioned functions. For this reason, the term "public service journalism" will be used cautiously. It should also be borne in mind that in the current media ecosystem few commercial media can be considered a healthier alternative, owing to the fact that media ownership is increasingly (1) more concentrated (Doyle 2002; Sánchez and Carvajal 2009) and (2) financialised, controlled by major global banking corporations and multinationals (Almirón 2010; García-Santamaría 2016).

Secondly, organised journalism is also a normative force defining the journalism provided by public service television stations. In November 2015, the International Press Institute (IPI) issued a report, after a drawn-out investigation starting in December 2014, including a process of listening to and dialoguing with social actors (over 30 different bodies), and above all with representatives of organised journalism.

This report contained seven warnings about the quality of public communication in Spain: (1) the lack of guarantees for the independence of public radio and television broadcasting; (2) the absence of independent control mechanisms for issuing radio broadcasting licenses; (3) the lack of transparency in the distribution of institutional advertising; (4) legislation on transparency far-removed from international standards; (5)

\footnotetext{
${ }^{2}$ In Moe Hallvard (2010, 3).
} 
potentially restrictive laws affecting the freedom of information, such as the Citizens' Security Act; (6) the common practice of press conferences without questions; and (7) defamation laws also in non-compliance with international standards.

Concerning the specific warning about the national public broadcasting corporation RTVE, the report also condemned the lack of independence, information manipulation practices, the pressure brought to bear on professionals and the internal purges. It insisted particularly on the seriousness of these issues, stressing that they had merited the attention of the international press, thus issuing a warning that went beyond personal and/or partisan grievances.

Thirdly, since policies are also a fundamental component of the public service journalism framework, the three key reference sources currently defining the normative structure in Spain as regards RTVE will be described briefly below:

1. In 2006, Act 17/2006 made it possible to advance towards a more participatory and less institutionalised RTVE, both called for and welcomed by academics in the field (Humanes and Fernández 2015; Lamuedra 2012; Fernández et al. 2010; Bustamante 2010; Zallo 2010), in pursuit of consensus principles such as social cohesion, cultural diversity, participation, access, independence, neutrality, quality, transparency and objectivity. This was brought about by implementing a number of changes: the appointment of its director-general and executive committee by Parliament (instead of the government); a greater involvement of professional journalists in the corporation's newscasts (news councils); and a schedule freely accessible to civil society thanks to the Right of Access and to have a voice in public service media, although it has been scarcely developed by TVE to date (Callejo 2002, 203-205); and the creation of a national audio-visual regulator (which has not been fully developed yet).

2. During the second term in office of Premier Rodríguez Zapatero, representing the Spanish Socialist Workers' Party (PSOE), Parliament passed General Act 7/2010 on Audio-visual Communication, which advanced towards deregulation and media ownership concentration (ULEPICC 2006; Díaz 2012, 129). For the purpose of this paper, it is worth noting that six out of the Act's 71 articles referred to "the rights of the public", although none of them envisaged mechanisms to uphold them. In short, participation implied that individuals could complain, indirectly and with no binding legal effect, about what television companies did or did not do, in line with what they themselves had established in their own self-regulatory frameworks.

3. When the conservative People's Party (PP) arrived in office, Royal Decree-Law 15/2012 was passed to allow the director-general and executive committee of RTVE to be appointed by a simple majority in Parliament. In other words, these appointments were now directly controlled by the political party in power.

In summary, the 2006 Act paved the way to improvements as regards public service journalism, which from 2007 to 2012 was the most popular and best valued in Spain (García de Madariaga, Lamuedra, and Tucho 2014, 911). Its full potential was never developed, however, as the Right of Access and the Audio-visual Regulator never worked as they were meant to (Callejo 2002). Moreover, the effects of the 2010 and 2012 reforms have had a very negative impact on viewership and public appreciation (Alonso, Broullón, and Lamuedra 2016).

Nevertheless, RTVE provides the only news services which still remain under a certain degree of democratic scrutiny by two bodies: (1) a parliamentary commission and (2) the news councils, which represent the voice of journalists to ensure compliance with the News Statute, an ethical code for journalistic practice at RTVE.

In short, the legal framework of the Spanish media ecosystem can be described as: 
- Insufficient. Professionalism in journalism, especially the public service kind, is the guarantor of the right to receive accurate information enshrined in the Constitution. However, neither this nor the right of social groups to have a voice in the mass media is guaranteed.

- A regression as regards controlling media ownership concentration, pluralism and independence at RTVE and in the media system as a whole.

\section{Methodology. An approach to the social perception of journalistic practices at TVE by means of a reception analysis}

In the previous sections, we have offered a brief overview of the ND within whose boundaries metajournalistic discourses on public service journalism develop. The time has now come to explore the AD on public service news programmes resulting from the activity of five discussion groups held in Spain during 2015. Specifically, the analysis focused on the following research questions:

1: How do citizens view the role of journalism and the role of public service journalism in democracy?

2: Do citizens' metajournalistic discourses on public service journalism coincide with the academic and political consensus (ND) on truthfulness, contrast, pluralism, independence, access and participation?

Our object of study is the social perception of the news media and information in general, thus we opted for qualitative techniques, specifically discussion groups, due to the fact that "the forms of social circulation of discourses are hardly observed in any other way than being in specific circulation" (Callejo 2000, 18).

We departed from the assumption that the economic turmoil, social unrest and "Indignados" movement ${ }^{3}$ had heightened awareness about the strategic role of journalism in society. Indeed, this movement was created without the usual involvement of representative institutions - political parties, trade unions, etc. - to denounce its unsatisfactory performance: "They do not represent us!" was its motto, which also went for journalism. In fact, the failure of journalism has been singled out as a very influential idea both during and after the protests (López 2013, 9) and has favoured a recent revitalisation of media and communicational experiences by social movements and non-profit organisations, which are currently shaping an emerging sector on the margins of the public and private media ecosystem (Barranquero and Meda 2015).

The main targets of the study were sectors whose awareness of the problems facing journalism, particularly the public service kind, was more likely to have been heightened by the context described: (1) "indignados"/activists and (2) those involved in or linked to the executive apparatus of public service in the field of cultural reproduction - excluding public television - i.e. museums, foundations, research and education centres, etc. They had been among the first to suffer from the government's austerity politics and were just beginning to recover the public's respect for their services.

Since this was the moment at which social media had taken off we also set out to explore the discourses of active (3) Internet users, a group of people under 30 years of age, except in one particular case.

After analysing these three discussion groups, we decided to incorporate new profiles in order to explore the extent to and the way in which this heightened awareness could have also affected the discourses of other social sectors. Having detected a recurrent left-wing ideological orientation, and a tendency towards university profiles in participants, two groups were designed: (4) people with a conservative ideology and (5) people without higher education.

\footnotetext{
${ }^{3}$ In Spain, also known as the 15-M movement.
} 
Internally, in each group the sample was varied enough as regards three criteria: age, gender and socio-economic status. ${ }^{4}$ In relation to their size, we adopted the approach suggested by Javier Callejo (2002, 418), to wit, from six to eight people.

\section{Table 1: Discussion groups details}

\begin{tabular}{l|l|l|l|l|l|} 
& Activists & Surfers & Public sector & Conservative & $\begin{array}{l}\text { Without } \\
\text { higher } \\
\text { education }\end{array}$ \\
\hline City & Seville & La Laguna & Madrid & Seville & Seville \\
\hline Date & $6 / 03 / 2015$ & $17 / 03 / 2015$ & $27 / 04 / 2015$ & $29 / 05 / 2015$ & $14 / 07 / 2016$ \\
\hline Moderator & C. Mateos & C. Mateos & M.Lamuedra & M. Lamuedra & M. Broullón \\
\hline
\end{tabular}

The discussion groups were identified with an acronym - "Surfers" (S), "People without higher education" (SES), "Public sector employees" (SP), "Conservatives" (C), "Activists" (A) - and each member as follows: subject (S)+number (e.g. SES-S1 or T-S5).

The discussion groups were conducted with minimal intervention from the moderator, who had to ensure that the following issues were addressed:

1. News consumption: most frequently viewed media; media specifically viewed for their news programmes; and TVE viewing time and habits.

2. Journalistic standards and values and their role in democracy.

3. Public service journalism specificity: differences with commercial media journalism.

4. Noted trends in TVE news.

5. Connection with the audience and recognition: the extent to which people feel that public service journalism reflects their work, problems or concerns; and the extent to which they remember news stories and use them in making decisions.

Most of these questions/topics appeared naturally during group conversations. Sessions started with a question about viewing habits introduced by the moderator. Discussions on news values, the crisis of credibility, the role of public service journalism and how it differed from the commercial kind tended to appear naturally in the conversations with minimal intervention from the moderator who, on the other hand, normally had to prompt group members on Topics 4 and 5.

In order to meet the study objectives, the discourse analysis categories used here to interpret data derived from the ND described in previous sections. The results are grouped in two lines of argument which respond to the research questions. The term "audience" is used here as a synonym of viewers or citizens.

\section{Results. Audience discourses on journalism}

First and foremost, we will map audience discourses on the role of journalism and public television in democracy on which there was a consensus in all the groups. These can be

\footnotetext{
${ }^{4}$ Although representativity was not the aim of this study, a reasonable degree of diversity was needed to make sure that different positions were taken into account. Thirty subjects took part in the discussion groups: 18 men and 12 women. Five of them were aged over 55, 12 between 36 and 55 and 21 under 35 . Subjects with a lower socio-economic status were reckoned with by creating a focus group of people without higher education. Geographical diversity was achieved by creating the groups in different provinces, although this variable has not proved to be significant for the analysis.
} 
explained as a dichotomy: on the one hand, the conception of "what they should be like" and, on the other, the censoring of or complaints about the current state of affairs.

"A democracy-orientated space for public opinion: debate, co-existence and voting". This idea was present and generated consensus in all the discussion groups: the mass media shape, or should shape, a space for public opinion and dialogue associated with the capacity of citizens to make decisions and to vote and, therefore, with their democratic rights and obligations, coinciding with the definition of the aforementioned legal and academic framework. Here are some examples:

It's a public service, because we all have the right to be informed; besides, it's in their interest, among other things. Why? Because there're some ballots (...) there're elections, yes, indeed, if there was no information, no-one could vote, or do anything else, or discover what's happening in the world, because that's also important, isn't it? Because it's a way of staying connected in your country (SES-S8).

I believe you have to be informed in order not to isolate yourself from the world, because (...) we're social animals, if we didn't socialise, I don't know what we'd be. We'd live totally on the margins and we need to know everything so as to have our own criteria, so as to form an opinion, because it's senseless to talk about things we have no idea about (C-S3).

The source on which the citizenry relies to keep track of what's happening in the news (...) they're the mirror in which we look to think about reality (A-S2).

"But at the service of the establishment". The second discourse on the function of the news ecosystem shared by all the groups was that - despite the fact that there was a general consensus on its strategic role in society - it was currently under the control of vested interests. This perception appeared integrated in a conception that assumed that such a system:

1. Has an owner: it is under the domination and control of a super-subject.

2. Represents the establishment: it influences and stage-manages reality.

3. Is a power at the service of those who wield instituted power (Castroriadis 1975) and strive to maintain the status quo.

4. Implies a vision of journalists as hostages of the political and economic powers.

The following paragraphs illustrate the existence of each of these interconnected discourses. First of all, it should be noted that the AD always revolved around "them" and the tension between that "them" and "us", "the people". For instance, S-S1 argued, "they don't give you that news, they conceal it, they conceal it, and they do so because they aren't interested in people protesting about that." The subject to which the pronoun "them" referred was represented as a super-subject because it was seen as a web, an articulated group, "something co-ordinated" between different spheres, mainly the economy and politics:

It's impossible because the state finds its way into private companies of all kinds (...) the owners of the press are those who wield political and economic power (S-S2).

I see it as something like a new, like a power, that is, like that famous separation of powers of Montesquieu (...) a high political content, something important in what politics is (...) for the quality of the democratic functioning of society, and in that sense it seems to me that it's a new power (A-S3).

An analysis of the group sessions shows that there was a consensus on the existence of a power relationship in which only a one-way influence between both extremes was mentioned. In this connection, SP-S1 said that it was the media's job to maintain the idea that "there's no 
possible alternative to the current political and economic system", supporting this claim with the assumption that if a minority amassed enormous wealth, this would be beneficial for the whole, since it would distribute the crumbs of the feast among society. S-S3 indicated that the coverage given by La Sexta ${ }^{5}$ to the discourse stemming from the social protests of the "Indignados" Movement acted like a safety valve by convincing those outraged by the situation that it was possible to take action from within the system. SES-S1 believed that the excess of news functioned like a moral millstone round people's necks, preventing them from moving forward.

In this regard, the media would be trying to encourage people to accept the status quo and to contribute to solving the problems of social dissatisfaction with the current state of affairs.

The media were blamed for their dependency on the political and economic establishment, rather than rank-and-file journalists who were seen as having to withstand a lot of pressure for fear of losing their jobs (A-S2). This situation stemmed from a problem of confidence and credibility, which public employees compared with the confidence that car owners had to place in a mechanic. In agreement, A-S5 declared, "it ends up jeopardising our right to be properly informed."

In light of the above, it can be claimed that the respondents perceived the effects of media concentration and financialisation (Doyle 2002; Almirón 2010), even though this knowledge of the media ecosystem did not seem to be shared by all. Hence, the trends presented below correspond to Nielsen and Graves' $(2017,5)$ observation about "a longrunning scepticism towards journalists, news media and politicians". Our analysis allows us to confirm this trend in the Spanish case, although excluding rank-and-file journalists, who are not held responsible for this situation.

Secondly, when exploring viewers' perceptions about the effects of such shortcomings on the news diet, a high degree of consensus among the respondents as regards these issues can be observed:

"Inadequate representation of issues and collectives". Four out of the five groups offered examples of when the media had presented issues or collectives, of which they had first-hand knowledge, in an inadequate way. In the People without Higher Education Group, two women with young children complained about the negative media representation of young people. In the Public Employee Group, a Chinese exchange student talked about the negative image that the media offered of his country and his compatriots residing in Spain, and explained that he did not feel represented; while two female scientists complained about the scant news coverage that science received and about common errors in its representation. In the Surfer Group, there was a consensus that the media "tried to convince us that the 'Indignados' was a neo-hippie movement, when it was actually made up of middle-class people of all ages" (S-S3).

"Misleading superficiality". Superficial news presentation was associated with failed representations, which was ultimately in the interests of that all-powerful super-subject. SESS8 spoke from personal experience and offered an illustrative example: after accepting a contract to work four and a half hours a day, she had not been included in the unemployment figures for a month, and agreed with SES-S3 that the news coverage of the unemployed was superficial and restricted to big numbers, without delving deeper into the problem, thus allowing it to be represented in favour of the interests, in this case, of the official discourse on the fall in unemployment.

"Greater scope and relevance as regards the information diet". In line with the aforementioned, the viewers considered that the information diet (1) needed to have a greater

\footnotetext{
${ }^{5}$ The only TV channel which tends to be considered left-wing in Spain.
} 
scope. For instance, SP-S5 explained that, culturally speaking, the media (including TVE) (2) did not give sufficient coverage to more relevant matters, which is clearly illustrated by CS4's complaint about the absence of news dealing with the Transatlantic Trade and Investment Partnership (TTIP). Similarly, among the surfers there was an interesting discussion, introduced by S-S4, a biologist, about how the media were ignoring the dangers of climate change and marine pollution, which she believed to be of utmost importance for public opinion.

It should be noted that the three aforementioned trends pinpoint problems in the representation of the news: the misrepresentation of identities, superficiality and the selection of what is to be covered (again) ${ }^{6}$.

Thirdly, audience discourses defined the function of public media as regards journalism as "a space of rights". Public media were considered the best option for generating that realm of public opinion relating to debate, decision-making and democracy. ${ }^{7}$ As a matter of fact, they were mentioned as a "benchmark" for what the system outlined above "should be like" (Surfer Group), a space for meeting and social cohesion: "they have to cater to all audiences; they cannot only cater to those who're left- or right-wing, or whatever..." (SES-S3).

It was identified, moreover, as a collective space (SP-S1), as "ours" (SP-S5) relating to emotional ties and family tradition: "always, since a child, no, I don't always watch it, I don't know, my father watched it in his time and my grandmother watched it in hers" (SES-S5). The testimony of SP-S6, who recounted the experience of losing the regional public service in Valencia, in the interpretive framework described above, was particularly heartfelt: "if you talk about emotion, it's helplessness".

Moreover, the public media were regarded as a space that afforded shelter from the dynamics inherent to the Spanish economic system, moved by profit above and beyond any value: "when there's a public information service, democracy is enriched, and when the priority of information is profit (...) we all lose out" (S-S2). This space was also associated with education (in three groups) and health, the defining traits of the welfare state for all the groups.

The predominance of this element, among other defining features of public service journalism, could be seen more clearly when the discussion groups were asked what would happen if public service broadcasting were to disappear, a question normally introduced by the moderator at the end of group sessions. If this were indeed the case, "we'd be left at the mercy of beasts and vipers" (SP-S6).

It was also acknowledged again that its current government dependency prevented the public service from accomplishing its "true" function, even though it was considered a space for which it was still worth fighting (Conservative, Public Employee, Surfer and Activist Groups), that should be built collectively (Surfer and Activist Groups) and that should emerge in the future. And if that possibility were killed off, "they would have beaten us" (C-S6).

Consequently, a set of specific features and demands emerged in the discussions on public service journalism. Independence, regulation, depth of information, pluralism and participation were the most regularly mentioned values, albeit not always appearing as clear/express or defined demands:

Independence. With respect to independence there was indeed an overall agreement on its absence at TVE, for which its administrators were blamed, rather than its rank-and-file journalists. And there was also a clear demand in all the groups about the need for independent public service journalism. It was generally held that the best way of guaranteeing independence was to "allow journalists freedom". The Surfer, Public Employee and Conservative Groups commented on the complaints filed by the News Council about news

\footnotetext{
${ }^{7}$ The alternative allowed by the advent of the Internet was also discussed (Surfer Group).
} 
dependency on the government's interests. The choice of director-general (SP-S1) was also mentioned as a specific way of ensuring both independence and pluralism. However, the group that put forward the largest number of ideas about how to achieve an independent model was that of the activists:

It's essential to go a bit further. That the scheduling isn't, isn't sufficient. That it's the control of the management of the mass media that should be in the hands of citizens. Because if the control remains in the hands of the politicians for whom we vote every four years, ultimately those programmes will... although they appear to be free, independent, they won't be (A-S2).

Pluralism. The term "pluralism" was used explicitly by the Public Employee, Surfer and Activist Groups. Even though it was not employed by the People without Higher Education or the Conservative Groups, both complained about the media's limited approaches. The lack of pluralism was also referred to as part of a broader problem, although no solutions to overcome it were mentioned. For instance, the Public Employee Group associated it with issues already covered above - such as the representation of China - while accepting its shortcomings and calling for greater pluralism, as if it were something so basic that it would not require further explanations.

Pluralism was also associated with the idea of cohesion, a space accommodating different ideologies, minorities and majorities which was lacking. The Surfer Group considered it an advantage characteristic of the Web, which could be organised according to collective intelligence, although there was no consensus in this regard: the oldest member of the group held that pluralism was mere window dressing and, if it did exist, would be domesticated by the system. Moreover, both the Surfer and Activist Groups voiced their concern about the Web's tendency to create individualistic and self-referential spaces. The Public Employee Group concurred that public media should build this meeting space.

Participation. Participation was formulated as a specific demand in some groups, above all by the surfers and activists. For instance, S-S2 believed that for the public service to function properly "we all have to collaborate a bit in its construction, to learn to demand a bit more and to construct and to do our bit towards calling for that public service, rather than waiting for it to be done the other way round from top to bottom". On the other hand, this topic was not mentioned at all in the Conservative and People without Higher Education Groups.

As regards both the public service and the system in general, the Surfer Group harboured the hope that reactive participation in public service journalism, "in peer control, the fact that you as a viewer can criticise the content they're offering you" (S-S5), would make a difference. This participation was viewed as more open and proactive as regards the Web (S-S3).

For its part, the Activist Group insisted on a public service that had to be participated in, constructed and decided on by the people. Organisational issues were touted as the key to the model: who had to decide, how, when and with what policy. Moreover, this group put forward an argument that linked participation to independence, an aspect that was not addressed by any other group. In this way, its members recognised that the responsibility lay with ordinary people in order to make sure independence was guaranteed, although several possibilities and measures to achieve this goal were discussed and problematised. As A-S5 stated, "if we want media that are really independent and that, and that are at our service, we're the ones who have to achieve this." Moreover, participation was relevant to this group for more comprehensive reasons. A-S3 developed the idea that participation empowered communities and thus fostered a more advanced democracy, an idea that was firmly seconded by all the participants. 
Deep coverage. It was occasionally difficult to draw a line between the attributes employed to describe public service journalism and the demands made of it. For instance, although there was full agreement on the need for more in-depth news coverage, no clear demand was voiced in this respect. It was just a mere diagnosis, as can be seen from the following extract:

(...) then you take a look at the editorial lines and you see that they're very feeble (...) and the debates are odd, with three men who don't actually enter into a debate. They're three men, each of whom voices his opinion, nothing is actually addressed (C-S5).

Independence and pluralism can be considered to be characteristic demands of the "professional model of journalism", as defined by Singer (2003), with a strong focus on expertise, public orientation and independence. Besides, the general call for participation, complexity, greater scope and issues of representation could be understood as the desire for changes in this model that take a more positive view of the motivations of audiences as regards knowledge and capabilities. This conclusion seems to be consistent with the findings of two studies, conducted in the Netherlands and Germany, dealing with accountability and audience inclusion, respectively. In the Netherlands, a country where faith in the media ecosystem is greater than in Spain, viewers' demand for "a stronger professionalization of journalism", and also greater accountability, stresses their desire to broaden their knowledge and to propose topics that they believe to be important and meaningful. ${ }^{8}$

Lastly, the discussion analysis suggests that although the diagnose about the quality and limitations of the media system in democratic practice were identical across groups, different proposals for addressing the problems emerged. Indeed, some expectations of and proposals for reversing critical or undesirable aspects showed different trends across groups.

The most clear-cut demand or suggested measure to deal with the current problems was to reinforce media regulation. This solution was debated in three of the five groups (Surfers, Public Employees and Activists), with the public employees developing it most: the conversation revolved around a regulation that guaranteed the independence of media professionals, similar to legislation passed in other European countries.

We believe that this trend is particularly interesting, given that the hegemonic media discourse has traditionally imposed the argument that the regulation of the media infringes upon freedom of expression (see, for instance, Álvarez-Peralta, 2017). And it is also in line with media democracy activists such as the Media Reform Coalition in the UK, focusing on policymaking (Brevini and Schlosberg 2016).

Two other groups debated other possible ways:

1. the idea that individual personal action by using technological resources made it possible to overcome at least some of the system's flaws predominated in the Surfer Group;

2. for the activists, the way of overcoming them was preferably by means of proposals for collective participation in the media so as to reshape them from within; $;^{9}$

And lastly, the Conservative and People without Higher Education Groups harboured the hope of future improvement, but did not explain how this could be achieved. Therefore, it can be observed that the need for media reform emerged in a more explicit and elaborated way in the discourses of those groups participating more actively in social protests or on the Internet or closer to public services in general.

\footnotetext{
${ }^{8}$ This discussion is developed in another paper (now in the process of publication) offering a detailed analysis of viewers' demands for participation and voice.

${ }^{9}$ A process that can be clearly seen in the creation of a professional online newspaper space, supported by citizens' subscriptions, in Spain over the past decade (Informe Annual de la Profesión Periodística, 2015: 65-66).
} 


\section{Conclusions}

The first set of conclusions explore the discursive correlations among social, legal, professional and academic frameworks. All things considered, it can be claimed that citizens' views and discourses as regards the media and public service journalism coincide to a great extent with the conceptual framework sustained by the academic community, legislation and professional practices. Social, legal and academic discourses seem to revolve around a number of central and potentially metadiscursive ideas, which can be summarised as follows:

1. Journalism is essential for citizens to form an opinion, vote and interact socially as part of a community.

2. Commercial journalism works for third parties in maintaining the status quo. Although viewers were critical towards this notion, their discourses also expressed resignation and frustration. According to della Porta $(2013,28)$, media studies take the structure of the mass media basically for granted. In this connection, the viewers' discourses were based on this same logic and they seemed to accept the current structure as part of "the natural order of things". There was much criticism of its functioning, but not so of its structural premises. Only the discourse of the activists broke with this tendency.

3. Public service journalism was seen as the most natural instrument to provide good journalism at the service of democracy. The AD was consistent insofar as the general opinion was that this mission was not being adequately accomplished and there was less resignation. Again, this echoes McChesney's (2007) claim about the role of public service broadcasters in improving information ecosystems.

Even values relating to quality journalism coincided to a great extent in the AD and ND: truthfulness, associated with the professionalism and independence of journalists; pluralism; participation; and cohesion. The need for more relevant and in-depth news coverage recognised by the viewers in all the groups rationally dovetailed with the normative and legal frameworks described above. In other words, viewers' discourses develop within the boundaries established by normative discourses and professional practices.

Secondly, the results provide relevant insights into the role of the legal framework of public service journalism in viewers' perceptions. There was also a certain general awareness of the impact of the legislative change that allows the political party in power to appoint the director-general of TVE, or the existence and role of the News Council, on government dependency. ${ }^{10}$ The only group in which these issues were not raised was the one made up of people without further education. This seems to indicate once again that knowledge in this respect has more to do with educational background than with the other variables explored.

Nonetheless, the discussion group members were less familiar with parts of the legal framework that have been barely developed or not all, such as the Right of Access or the Audio-visual Regulator, despite the fact that the regulation of the media, especially the public channels, and participation figured among their demands.

Lastly, an also very unknown piece of legislation affecting journalism was the SC: the group members were unacquainted with the fact that many of their demands were constitutional rights; for instance, not even the activists keen on fostering media participation knew that this is a constitutional right. Moreover, in relation to the journalism of the commercial channels and public media there prevailed a reactive perception of this right - to control or to complain about content - in agreement with the legal framework in force (again, with the exception of the activists).

\footnotetext{
${ }^{10}$ The most prudent conjecture is that the time and effort that the News Council has dedicated to denouncing these issues in the media and different institutions have put them on the news agenda. However, no study has been undertaken as yet to confirm this possibility.
} 
Thus, the legal normative framework also has a significant, albeit limited, influence: only the most educated are familiar with the most important regulations in place, and even then they are unaware of some key aspects.

Thirdly, interpreting data from the perspective of metajournalistic theory helps us to identify revealing trends as regards audience discourses:

1. Viewers do not perceive themselves as subjects capable of intervening in the definition of journalism and its rules, and therefore as speaking subjects. This is in line with the findings of Van der Wurff and Schönbach $(2014,134)$ about audience expectations of media accountability in the Netherlands, and points to the social prevalence of the model of professional journalism (despite some tensions and disaffections).

2. Viewers seem to be "culturally distanced" from journalism, a phenomenon already identified by Williams $(1982,32)$ : they assume that journalism is a field with rules that journalists accept and obey. This is consistent with the previous comment: journalism is the work of journalists.

3. Viewers take different stances on journalists. On the one hand, they place them on the other side, that of the media. And in this connection they do not identify with them, envisage any possibility of collaborating with them or conjure up situations in which journalists and citizens can play a joint role. But on the other, they show a certain degree of sympathy for them and recognise that they are workers like any others, who also live in fear of losing their jobs. Therefore, the only indication that viewers identify with journalists can be glimpsed not in the social construction of metajournalism, but in a certain feeling of solidarity as victims of the super-subject who is hindering the effective development of journalism. Therefore, they seem to believe in professionalism, should this really exist.

Besides, as regards the notion of participatory journalism: (1) the general criticism of the way in which journalistic "representation" (misleading, superficial and of a limited scope) serves the interests of third parties may substantiate a social demand for a more participatory conception and practice of journalism. And, as observed below, the discourse of the activists (plus a few members of other groups) broke with the general tendency towards reactivity. In fact, it can be described as generative inasmuch as it not only connected with the most critical academic stances on journalism, but also explored conversationally new media ecosystem designs beyond hegemonic normative conceptions. Since critical academic perspectives may have "descended" from the "ivory tower" to the streets during the cycle of protests, the discourse was especially present among "Indignados" activists, while other features were also consensual across groups. ${ }^{11}$

And finally, as regards the prospect of media reform, this paper has been devised as an exercise of "generative metajournalistic discourse", as it aims to provoke a wider debate on journalism. Previous conclusions have contributed to plot a map of the ideas already circulating transversally in society with respect to (1) the scope of the democratic deficit in the current design of the media system, and (2) what possibilities for reform already have a certain amount of support and in which social sectors. The discussion of the results provides useful data for those members of the academic community who see scientific knowledge as a tool to intervene in the democratic and civic development of society. At the present juncture it is useful to bear in mind the following trends: (1) there is a general consensus that public service media should shelter citizens from partisan and self-serving information and (2) the opportunities that the Internet offers users to contrast different media voices are also viewed 
by citizens as a possible ally in limiting the power of the "establishment", and (3) regulations aimed at guaranteeing pluralism and journalists' independence may have public support.

\section{REFERENCES}

Almirón, Nuria. 2010. Journalism in Crisis. Corporate Media and Financialization. New York: Hampton Press.

Alonso, Elisa, Manuel Broullón, and María Lamuedra. 2016. "Empirical analysis of the dynamics of remediation between television and the Internet in Spain: the discourses of users." Revista Latina de Comunicación Social 71: 179-196.

Álvarez-Peralta, Miguel. 2017. "Demandas de reforma mediática y momento populista. La circulación de las propuestas de democratización de los medios en el espacio político postbipartidista”. IC-Revista Científica de Información y Comunicación 14: 121-157.

Aslama Horowitz, Minna, and Hannu Nieminen. 2017. "Diversity and Rights. Connecting Media Reform and Public Service Media." IC-Revista Científica de Información y Comunicación 14: 99-119.

Azurmendi, Ana. 2005. "From Journalistic Truth to the Constitutional concept of Accurate Journalism. Rethinking the required truth in the exercise of Press Freedom." Communication \& Society 18 (2): 9-48.

Barranquero, Alejando, and Miriam Meda. 2015. "Los medios comunitarios y alternativos en el ciclo de protestas ciudadanas desde el 15M." Athenea Digital 15 (1): 139-170.

Born, Georgina, and Tony Prosser. 2001. "Culture and consumerism: citizenship, public service broadcasting and the BBC's fair trading obligations." The modern law review 64 (5): $657-687$.

Brevini, Benedetta, and Justin Schlosberg. 2016. "Between philosophy and Action. The Story of the Media Reform Coalition." In Strategies for Media Reform, edited by Des Freedman, 123-137. New York: Fordham University Press.

Bustamante, Enrique. 2010. "La contrarreforma audiovisual socialista." Le Monde Diplomatique en español, February 8.

Callejo, Javier. 2000. El grupo de discusión: introducción a una práctica de investigación. Barcelona: Ariel.

Callejo, Javier. 2002. "Observación, entrevista y grupo de discusión: el silencio de tres prácticas de investigación.” Revista Española de Salud Pública 76 (5): 409-422.

Castroriadis, Cornelius. 1975. La institución imaginaria de la sociedad II. Buenos Aires: Tusquest.

Carlson, Matt. 2016. "Metajournalistic Discourse and the Meanings of Journalism: Definitional Control, Boundary Work, and Legitimation." Communication Theory 26 (4): 349-368. 
Coleman, Stephen. 2002. "From service to commons: re-inventing a space for public communication." In From Public Service Broadcasting to Public Service Communications, edited by Jamie Cowling and Damian Tambini, 89-99. London: Institute for Public Policy Research.

Crouch, Colin. 2004. Posdemocracia. Madrid: Taurus.

Cushion, Stephen. 2012. The Democratic Value of News: Why Public Service Media Matter. Basingstoke and New York: Palgrave Macmillan.

Dahlgren, Peter. 2009. Media and Political Engagement: Citizens, Communication and Democracy. Cambridge: Cambridge University Press.

della Porta, Donatella. 2013. "Bridging Research on Democracy, Social Movements and Communication." In Mediation and Protests Movements, edited by Bart Cammaerts, Alice Mattoni, and Patrick McCurdy. Bristol: Intellect Ltd.

Díaz, Rafael. 2012 “El pluralismo interno, clave del Servicio Público de RTVE.” In El futuro de la televisión pública: La necesaria alianza con la ciudadanía, edited by María Lamuedra, 129-148. Madrid: Editorial Popular.

Doyle, Gillian. 2002. Media Ownership: The Economics and Politics of Convergence and Concentration in the UK and European Media. London: Sage.

Fernández, Isabel, Montse Bonet, Josep Ángel Guimerá, Mercé Díez, and Federica Alborch. 2010. "Spanish Public Broadcasting. Defining traits and future challenges following analogue television switch-off." Observatorio (OBS*) Journal 4 (3): 301-318.

García-Avilés, José A. 2011. "Dimensiones y tipología de las actividades de participación de la audiencia en la televisión pública." Ámbitos 20: 175-195.

García de Madariaga, José, María Lamuedra, and Fernando Tucho. 2014. "Challenges to public service news programmes in Spain: Professionals and viewers' discourses wavering between institutional reform and counter-reform." Journalism 15 (7): 908-925.

García-Santamaría, José V. 2016. Los grupos multimedia españoles. Barcelona: Editorial UOC.

Hackett, Robert A., and William K. Carroll. 2006. Remaking media: the struggle to democratize public communication. New York and London: Routledge.

Heise, Nele, Wiebke Loosen, Julius Reimer, and Jan-Hinrik Schmidt. 2014. "Including the Audience.” Journalism Studies 15 (4): 411-430..

Humanes, María L., and Isabel Fernández. 2015. "Pluralismo informativo y medios públicos. La involución de TVE en el contexto de cambio político (2012-2013)." Revista Latina de Comunicación Social 70: 270-287.

Humphreys, Peter. 2008. "Redefining Public Service Media: A Comparative Study of France, Germany and the UK." Paper presented at the 4th Annual RIPE Conference Public Service 
Media in the 21st Century: Participation, Partnership and Media Development, Mainz, October 10.

Informe Anual de la Profesión Periodística 2015. Asociación de la Prensa de Madrid. Accessed January 1, 2018. http://www.apmadrid.es/wp-content/uploads/2016/11/INFORMEPROFESION-APM-2015_baja_7M.pdf.

Lamuedra, María. 2012. El futuro de la televisión pública: la necesaria alianza con la ciudadanía. Madrid: Editorial Popular.

Larsen, Håkon. 2014. "The Legitimacy of Public Service Broadcasting in the 21st Century." Nordicon Review 35 (2): 65-76.

López, Guillermo. 2013. "Del 11M al \#15M. Nuevas tecnologías y movilización social en España." Revista Faro 16: 1-12.

McChesney, Robert. 2007. Communication Revolution: Critical Junctures and the Future of the Media. New York: The New Press.

McChesney, Robert. 2015. Rich Media, Poor Democracy: Communication Politics in Dubious Times. New York: The New Press.

McChesney, Robert, and John Nichols. 2010. The Death and Life of American Journalism. New York: Nation Books.

Mitchell, Amy, Simmons, Katie, Matsa, Katerina E, Silver, Laura, Shearer, Elisa, Johnson, Courtney Walker, Mason, and Taylor, Kylie. 2018. "Western Europe, Public Attitudes Toward News Media More Divided by Populist Views Than Left-Right Ideology." Pew Research Center. Available at: http://www.journalism.org/2018/05/14/in-western-europepublic-attitudes-toward-news-media-more-divided-by-populist-views-than-left-rightideology/.

Moe, Hallvard. 2010. "Defining public service beyond broadcasting: the legitimacy of different approaches." International Journal of Cultural Policy 1(17): 52-68.

Moe, Hallvard. 2008. "Dissemination and Dialogue in the Public Sphere: A Case for Public Service Media Online.” Media, Culture and Society 30 (3): 319-336.

Nino, Carlos S. 1997. La constitución de la democracia deliberativa. Barcelona: Gedisa.

Nielsen, Rasmus K., and Lucas Graves. 2017. "News You Don't Believe: Audience Perspectives on Fake News". Oxford: Reuters Institute for the Study of Journalism.

Sánchez, Alfonso, and Miguel Carvajal. 2009. Media Concentration in the European Market: New Trends and Challenges. Pamplona: Servicio de Publicaciones de la Universidad de Navarra.

Schlosberg, Justin. 2013. Power Beyond Scrutiny: Media, Justice and Accountability. London: Pluto Press. 
Schmidt, Siegfried J. 2008. "Operative Fictions, Or: How to talk about society. Constructivist Foundations. An Interdisciplinary Journal 3 (2): 67-68.

Steemers, Janette. 2001. "In Search of a Third Way: Balancing Public Purpose and Commerce in German and British Public Service Broadcasting." Canadian Journal of Communication 26: 69-87.

Serrano, Pascual. 2010. Traficantes de información. La historia oculta de los grupos de comunicación españoles. Barcelona: Akal.

Singer, Jane B. 2003. "Who are these guys? The online challenge to the notion of Journalistic Professionalism.” Journalism 4 (2):139-163.

ULEPICC. 2010. "Proyecto de Ley General de la Comunicación Audiovisual/Reforma y contrarreforma en la política de comunicación audiovisual del Gobierno de Rodríguez Zapatero." Available at: http://www.ulepicc.es/web/documentos/DeclaracionULEPICC.pdf.

Van der Wurff, Richard, and Klaus Schönbach. 2014. "Audience Expectations of Media Accountability in the Netherlands." Journalism Studies 15 (2): 121-137.

van Dijck, José, and Thomas Poell. 2015. "Making public television social: Public service broadcasting and the challenges of social media." Television \& New Media, 16 (2): 148-164. https://goo.gl/CqyxQy https://doi.org/10.1177/1527476414527136.

Williams, Raymond. 1982. "Distance." In What I Came to say, edited by Alan O'Connor, 172-192. London: Hutchinson Radius.

Velasco, Juan C. 2009. "Democracia y deliberación pública." Confluencia XXI. Revista de Pensamiento Político 6: 70-79.

Zallo, Ramón. 2010. "La política de Comunicación Audiovisual del gobierno socialista (2004-2009): un giro neoliberal.” Revista Latina de Comunicación Social 65: 14-29.

This paper forms part of the "Dinámicas de relación ante el cambio social: contextos, contenidos, productores, público y produsuarios en las noticias de TVE e YLE" (CSO2013-45470-R) research project, financed by the Spanish Ministry of Economy and Competitiveness 2013 National Programme for Research Aimed at the Challenges of Society, and led by María Lamuedra and Manuel Ángel Vázquez Medel. This programme also received supporting funds from the European Regional Development Fund (ERDF). 